\title{
ASSESSMENT OF SERUM ZINC LEVEL IN CHILDHOOD EPILEPSY TREATED WITH LONG-TERM ANTI EPILEPTIC DRUG (AED)
}

\author{
Shamim-Ara-Sarkar ${ }^{1}$, Habibur Rahman ${ }^{2}$, Israt Jahan ${ }^{3}$, Sharmin Parveen ${ }^{4}$, Md Ranzu Ahmed ${ }^{5}$ \\ ${ }^{1}$ Holy Family Red Crescent Medical College \& Hospital, \\ ${ }^{2}$ Institute of Health Technology, Mohakhali, Dhaka, Bangladesh \\ ${ }^{3,4,5}$ Bangladesh University of Health Sciences (BUHS), Mirpur-1, Dhaka, Bangladesh.
}

*Corresponding Author: Israt Jahan

Corresponding Author Email: isratmostafiz@gmail.com, drranzubd@gmail.com

Article Received: $14-05-19$

Accepted: 29-05-19

Published: 05-06-19

Licensing Details: Author retains the right of this article. The article is distributed under the terms of the $\begin{array}{lllll}\text { Creative } & \text { Commons } & \text { Attribution-NonCommercial } & 4.0 & \text { License }\end{array}$ (http://www.creativecommons.org/licences/by-nc/4.0/) which permits non-commercial use, reproduction and distribution of the work without further permission provided the original work is attributed as specified on the Journal open access page

\begin{abstract}
Almost $85 \%$ of epilepsy patients which is a common neurolotical disease live in developing world. Mostly the disease start in childhood in more than half of the cases. Long term use of antiepileptic drugs may alter serum zinc level. The purpose of the present study was to assess the serum zinc level in childhood epilepsy treated with long-term Anti-Epileptic Drug (AED). This cross-sectional study was carried out in the outdoor and indoor patient department of Pediatric neurology, BSMMU during the period from March 2013 to August 2013. Sample size was one hundred, among these fifty were case e.g. epileptic child who had received anti-epileptic drugs (Carbamazepine and/or Valproic acid) for more than three months and fifty were control e.g. newly diagnosed epileptic child, who have not yet received antiepileptic drugs. In this study, among100 epileptic child, mean serum zinc level in case group was $0.36( \pm 0.20)(\mu \mathrm{g} / \mathrm{ml})$ and in control group was $0.52( \pm 0.26)(\mu \mathrm{g} / \mathrm{ml})$, which was statistically significant $(\mathrm{p}<0.05)$. The use of one drug or multiple drugs in the treatment of epileptic patients has made the significant low serum zinc level.
\end{abstract}

Keywords: Serum Zinc, Childhood, Epilepsy, Antiepileptic Drug, Long-Term. 


\section{INTRODUCTION}

Epilepsy is a recurrent, unprovoked, seizure manifested by an abnormal and excessive synchronized discharge of a set of cerebral neurons. The result of this discaharge is that patient suffer convulsive movements, disturbance of sensation, and loss of consciousness or combination. ${ }^{1}$ Epilepsy is a common neurological disease and its occurrence is about 3 to 20 people per 1000 in general population occurring more frequently in school children. ${ }^{\mathbf{1 , 2 , 3 4}}$ In It is estimated that there are 1.52 million patients of epilepsy in Bangladesh. A survey related to the Dasher Kandi, Bangladesh shows that there is about 2.54 patient in every 1000 population in Bangladesh. ${ }^{5}$ it is estimated that two third of epileptic seizures starts in age of less than 5 years and seizures assumes the most array of form. Trace elements (e.g. Copper, Zinc and Manganese) are minor building components in tissues including the nervous system. For maintaining human health, there is required balance in trace elements ${ }^{7}$. In peripheral and central nervous systems, trace elements function is vital ${ }^{8-13}$. Indispensable components for certain enzymes (such as glutathione peroxidases) include zinc, Selenium and Coooper which are responsible for brain metabolic processes ${ }^{14} 15$.

If there is excess or deficiency of trace elements in some patient so it can lead to some disease ${ }^{16}$. The function of anti-elipetic drug is to change the blood trace elements like Zinc and metabolism. . Sözüer et $\mathrm{al}^{20}$ measured serum Zinc (Zn) levels in 52 epileptic children who were treated with either Carbamazepine (CBZ) or Valproic acid (VPA) or with a combination of CBZ and VPA. Serum Zn levels were significantly lowers in the epileptics than in the two control groups which consisted of 7 untreated epileptics and 12 normal children.

\section{METHODOLOGY}

This cross-sectional study was carried out in the outdoor and indoor patient department of Paediatric neurology, BSMMU during the period from March' 2013 to August' 2013. Sample size was one hundred, among these fifty were case e.g. epileptic child who had received antiepileptic drugs (Carbamazepine and/or Valproic acid) for more than three months and fifty were control e.g. newly diagnosed epileptic child, who have not yet received antiepileptic drugs. Clinically diagnosed patient of epilepsy from 1 month to 18 years of age and treated with Carbamazepine and/or Valproic acid $\geq 3$ months were included in this study. Epileptic children with other systemic illnesses such as diabetes, renal failure, malnutrition or any infectious diseases and receiving antiepileptic drug for less than three months or receiving antiepileptic drug other than studied drugs were excluded from this study. Sample was selected by nonrandom sampling method. After proper selection of case \& control cases, complete history had taken from accompanying attendants. Through clinical examination was done. Relevant investigation reports were collected and recorded. Serum zinc ( $\mathrm{Zn}$ ) were measured by atomic absorption spectrophotometer ${ }^{17}$ The name of spectrophotometer is graphite furnance atomic absorption spectrophotometer (GF-AAS, 6650, Shimadzu: KYOTO, JAPAN) and analysis was done in biochemistry laboratory of BSMMU (Bangabandhu Sheikh Mujib Medical University) 
and ICDDR,B.( International Centre for Diarrhoeal Diseases Research, Bangladesh. After collecting all the data, analysis has been done by using SPSS.

\section{RESULT}

A total number of 100 children were enrolled for this study, out of which 50 were case and 50 were control. Mean age of study population was $4.39( \pm 2.34)$ years whereas case group was $4.08( \pm 2.21)$ years and control group was $4.70( \pm 2.45)$ years.

Table 1: Age group distribution of the study population

\begin{tabular}{|l|l|l|l|}
\hline & \multicolumn{2}{|l|}{ Study group } & \\
\hline Age group & Case/Epileptic & Control & Total \\
\hline $1-2$ years & $16(32)$ & $14(28)$ & 30 \\
\hline$>2$ to 5 years & $21(42)$ & $16(32)$ & 37 \\
\hline$>5$ years & $13(26)$ & $20(40)$ & 33 \\
\hline Total & $50(100)$ & $50(100)$ & 100 \\
\hline Mean \pm SD & $4.08( \pm 2.21)$ & $4.70( \pm 2.45)$ & $4.39( \pm 2.34)$ \\
\hline
\end{tabular}

Among the study population male female ratio was 1.63:1.

Table 2: Sex distribution of the study group

\begin{tabular}{|l|l|l|l|}
\hline & \multicolumn{2}{|l|}{ Study group } & \\
\hline & Epileptic & Control & Total \\
\hline Male & 31 & 31 & 62 \\
\hline Female & 19 & 19 & 38 \\
\hline Total & 50 & 50 & 100 \\
\hline
\end{tabular}

Table 3: Family history of epilepsy of the study group

\begin{tabular}{|l|l|l|l|l|}
\hline \multirow{2}{*}{$\begin{array}{l}\text { Family } \\
\text { Epilepsy }\end{array}$} & \multicolumn{2}{|l|}{ Study group } & & \\
\cline { 2 - 5 } & $\begin{array}{l}\text { Epileptic } \\
\mathrm{n}(\%)\end{array}$ & $\begin{array}{l}\text { Control } \\
\mathrm{n}(\%)\end{array}$ & Total & P value \\
\hline Yes & $17(34)$ & $08(16)$ & 25 & 0.001 \\
\hline No & $33(66)$ & $42(84)$ & 75 & \\
\hline Total & $50(100)$ & $50(100)$ & 100 & \\
\hline
\end{tabular}

Here, calculate the $\mathrm{P}$ value by using Chi-square test.

By the study on family history of epilepsy, it was found that, in epileptic group $34 \%$ had family history of epilepsy and in control group $16 \%$ had family history of epilepsy and that was statistically significant $(\mathrm{p}<0.05)$. 
Table 4: Character of seizure of the study population

\begin{tabular}{|l|l|l|l|l|}
\hline \multirow{2}{*}{ Character of seizure } & \multicolumn{2}{|l|}{ Study group } & \\
\cline { 2 - 4 } & $\begin{array}{l}\text { Epileptic } \\
\mathrm{n}(\%)\end{array}$ & $\begin{array}{l}\text { Control } \\
\mathrm{n}(\%)\end{array}$ & Total & P value \\
\hline Generalized tonic clonic & $39(78)$ & $36(72)$ & 75 & \multirow{2}{*}{$\mathbf{0 . 5 7}$} \\
\hline Tonic & $06(12)$ & $08(16)$ & 14 & \\
\hline Clonic & $03(06)$ & $04(08)$ & 07 & 04 \\
\hline Others & $02(04)$ & $02(04)$ & 04 & \\
\hline
\end{tabular}

Here, calculate the $\mathrm{P}$ value by using Fisher's exact probability test.

Table 5: EEG findings of the study population

\begin{tabular}{|l|l|l|l|l|}
\hline \multirow{2}{*}{ EEG findings } & \multicolumn{2}{|l|}{ Study group } & & \\
\cline { 2 - 5 } & $\begin{array}{l}\text { Epileptic } \\
\mathrm{n}(\%)\end{array}$ & $\begin{array}{l}\text { Control } \\
\mathrm{n}(\%)\end{array}$ & Total & P value \\
\hline $\begin{array}{l}\text { Generalized } \\
\text { seizures }\end{array}$ & $32(64)$ & $27(54)$ & 59 & $\mathbf{0 . 3 0}$ \\
\hline Focal seizure & $18(36)$ & $23(46)$ & 41 & \\
\hline Total & $50(100)$ & $50(100)$ & 100 & \\
\hline
\end{tabular}

Here, calculate the P value by using Chi-square test.

Study on EEG findings, it was found that generalized seizure in epileptic group were $64 \%$ were and in control group were 54\%. Focal seizure in epileptic group were $36 \%$ and in control group were $46 \%$, where $(p>0.05)$ had not statically significant

Table 6: Mean difference of serum zinc level of the epileptic group and control group.

\begin{tabular}{|l|l|l|l|}
\hline & \multicolumn{2}{|l|}{ Study group } & \\
\hline & Epileptic & Control & P value \\
\hline $\mathrm{Zn}(\mu \mathrm{g} / \mathrm{ml})$ & $0.36( \pm 0.20)$ & $0.52( \pm 0.26)$ & $<0.001$ \\
\hline
\end{tabular}

Here, calculate the $\mathrm{P}$ value by using unpaired " $\mathrm{t}$ " test.

Mean zinc level $0.36( \pm 0.20)(\mu \mathrm{g} / \mathrm{ml})$ was in epileptic group and $0.52( \pm 0.26)$ was in control group where $(\mathrm{p}<0.05)$ that was statistically significant.

Table 7: Mean $\mathrm{Zn}(\mu \mathrm{g} / \mathrm{ml})$ level between different anti-epileptic drugs

\begin{tabular}{|l|l|l|l|l|}
\hline & \multicolumn{2}{|l|}{ Epileptic patients } & & \\
\hline & Carbamazepine & Valproic acid & $\begin{array}{l}\text { Carbamazepine } \\
\text { andValproic acid }\end{array}$ & P value \\
\hline $\mathrm{Zn}(\mu \mathrm{g} / \mathrm{ml})$ & $0.38( \pm 0.25)$ & $0.41( \pm 0.23)$ & $0.31( \pm 0.13)$ & 0.03 \\
\hline
\end{tabular}

Here, calculate the P value by using "One way ANOVA test". It was done by SPSS software version -17. In 
multiple comparisons in between three drugs group $(\mathrm{p}<0.05)$ were significant.

After medication with carbamazepine(CBZ), valproic acid(VPA), carbamazepine and valproic $\operatorname{acid}(\mathrm{CBZ}+\mathrm{VPA})$ mean zinc levels were $0.38( \pm 0.25)(\mu \mathrm{g} / \mathrm{ml}), 0.41( \pm 0.23)(\mu \mathrm{g} / \mathrm{ml})$ and $0.31( \pm$ $0.13)(\mu \mathrm{g} / \mathrm{ml})$ respectively where $(\mathrm{p}<0.05)$ that was statistically significant.

\section{DISCUSSION}

Childhood epilepsy is a worldwide problem. Trace elements (e.g. Copper, Zinc and Manganese) are minor building components in tissues including the nervous system. This study has been designed to determine the levels of zinc $(\mathrm{Zn})$ in serum from patients with epilepsy in children who were taking anti-epileptic drugs (carbamazepine and/or valproic acid) for at least three months. This was a cross-sectional study among the patients who were consulted and admitted at the department of Paediatric neurology, BSMMU. In this study mean age was $4.39( \pm 2.34)$. In epileptic group mean age was 4.08( \pm 2.21$)$ and control group was $4.70( \pm 2.45)$. As compared with Tekinet al. ${ }^{21}$ study mean age group was $4.24( \pm 0.35)$ and case group was $4.69( \pm 1.12)$ that result was approximately similar to our study. Another study by Saboktakin et al ${ }^{24}$ also corroborates with our study. Diop et al's ${ }^{25}$ study in Senegal was limited to children aged between 1 to 9 years.

In this study sex distribution of epileptic group and control group have shown male female ratio was $1.63: 1$. A study by Nouri et al demonstrated that male-to-female ratio was $1.75: 1$.These results corroborate with our study. ${ }^{26}$

In this study, epileptic group had 34\% family history of epilepsy and in control group $16 \%$ had family history of epilepsy and that was statistically significant $(\mathrm{p}<0.05)$. Saboktakin et al demonstrated that the family history of epilepsy were positive in $9 \%$ of epileptic patients. ${ }^{24}$

In this study, $78 \%$ generalized tonic clonicseizures were in epileptic group and $70 \%$ were in control group. Tonic was $12 \%$ in epileptic group and $16 \%$ in control group. Clonic was $06 \%$ inepileptic group and $8 \%$ in control group, which was not statistically significant $(\mathrm{p}>0.05)$.

Ogunlesi $\mathrm{T}$ et al reported that generalized tonic-clonic seizures were the commonest seizure type of their study $(97 ; 76.9 \%)$. These were followed by tonic seizures $(8 ; 6.3 \%)$, clonic seizures $(6$; $4.8 \%)$ and myoclonus $(3 ; 2.4 \%)^{27}$ that match with this present study.

Following the clinical diagnosis of epilepsy in an individual Osuntokon B O et al demonstrated that it was usually recommended an EEG, amongst other investigations, be carried out. The EEG provides three types of information: confirmation of an abnormal electrical activity; information about the type of seizure disorder and the location of the seizure focus. ${ }^{\mathbf{2 8 , 2 9}}$ In this present study EEG findings, generalized seizure activity was $64 \%$ in epileptic group and $54 \%$ in control group. Focal seizure was $36 \%$ in epileptic group and $46 \%$ in control group and those results were not statistically significant $(\mathrm{p}>0.05)$. However, Meindari $\mathrm{H}$ et al 
conducted a EEG-based studies of epilepsy to show the frequency of seizure type. According to their literature, generalized seizures account for $45 \%$ of all seizure types, whereas focal seizures are present in $55 \%$ of cases. ${ }^{30}$ It is crucial to recognize that a normal EEG does not exclude epilepsy, as around $10 \%$ of patients with epilepsy never show epileptic form discharges. Secondly, an abnormal EEG demonstrating IED (interictalepileptiform discharge) does not in itself indicate that an individual has a seizure disorder, as IED are seen in a small percentage of normal subjects who never develop epilepsy and IED may also be found in patients with neurological disorders which are not complicated by epilepsy. ${ }^{31,32 .}$

In this present study mean zinc level was $0.36( \pm 0.20)(\mu \mathrm{g} / \mathrm{ml})$ in epileptic group and $0.52( \pm 0.26)$ $(\mu \mathrm{g} / \mathrm{ml})$ in control group which was statistically significant $(\mathrm{p}<0.05)$.Studies of Saboktakin et.al. $^{24}$, Barbeauset.al. ${ }^{23}$ and Verrotti et.al ${ }^{22}$ have also corroborated with the similar results of our study on serum zinc in epileptic patient under drug therapy. Saboktakin et al demonstrated that the mean zinc level in children with epilepsy under drug treatment was $0.36( \pm 0.13) \mu \mathrm{g} / \mathrm{ml}$ and $0.43( \pm 0.21) \mu \mathrm{g} / \mathrm{ml}$ in control group, which was lower meaningfully in epileptic patients. Although their control group were normal healthy subjects.Besides this, Verrotti'set al. ${ }^{22}$ have demonstrated no significant difference in the levels of other elements (copper and magnesium).

After medication with carbamazepine(CBZ), valproic acid(VPA), carbamazepine and valproic $\operatorname{acid}(\mathrm{CBZ}+\mathrm{VPA})$ mean zinc levels were $0.38( \pm 0.25)(\mu \mathrm{g} / \mathrm{ml}), 0.41( \pm 0.23)(\mu \mathrm{g} / \mathrm{ml})$ and $0.31( \pm$ $0.13)(\mu \mathrm{g} / \mathrm{ml})$ respectively where $(\mathrm{p}<0.05)$ that was statistically significant. Here we observed that combination therapy(CBZ+VPA) has more potentiality than monotherapy with CBZ or VPA for reducing serum zinc level of epileptic patients.

Studies of Sherifa et.al. ${ }^{33}$,Sözüer DT $^{20}$ et al have also corroborated with the similar results with our study on serum zinc in epileptic patients.Sherifaandcolleagues demonstrated thatserumlevelsofzinc inpatients with epilepsyontreatment(particularly withsodium valproate and carbamazepine)were low. ${ }^{33}$

In Sözüer DT et al ${ }^{20}$ demonstrated that zinc level was $0.27 \pm 0.10(\mu \mathrm{g} / \mathrm{ml})$ in patients treated with carbamazepine and $0.35 \pm 0.15(\mu \mathrm{g} / \mathrm{ml})$ in patients treated with sodium valproate. That result was showed carbamazepine was more effective than sodium valproate reducing serum zinc level of epileptic patients.

Yanagisawa et al reported that serum zinc level $31-59 \mu \mathrm{g} / \mathrm{dl}(0.31-0.59 \mu \mathrm{g} / \mathrm{ml})$ may or may not produce any symptom of zinc deficiency. They stated this reference range as deficiency state and suggested countermeasures this condition either by cause identification and removed as needed or dietary therapy(ingestion of zinc rich food) or zinc replacement. They mentioned that serum zinc level below $30 \mu \mathrm{g} / \mathrm{dl}(0.30 \mu \mathrm{g} / \mathrm{ml})$ as a definite deficiency state and produce clinical symptom like hair loss, diarrhea, delayed sexual maturation, impotence, hypogonadism, growth retardation, eye and skin lesions, weight loss, delayed healing of wounds, fever, pica, taste abnormalities, mental lethargy, intention tremor, depression, impaired concentration, nystagmus, 
dysarthria, night blindness, hypogeusia, anosmia, dementia etc. They recommended dietary allowance for zinc taken by mouth is: 2 milligrams oral zinc for 0 to six months of age; 3 milligrams for seven months to three years of age; 5 milligrams for 4-8 year-olds; 8 milligrams for 9-13 year-olds; 11 milligrams for 14-18 year old boy; 9 milligrams for 14-18 year-old girl. ${ }^{34-}$ 35 .

As antiepileptic therapy (CBZ,VPA,CBZ and VPA) has significant potentiality to reduce serum zinc level in epileptic patients that may lead to morbidity due to zinc derangement therefore, repeated monitoring should be carried out.

\section{CONCLUSION}

The use of one drug or multiple drugs in the treatment of epileptic patients has made significant differences in the levels of serum zinc. The serumlevelof zincinpatientundertreatment with carbamazepine and/or valproic acid was significantly lower.

\section{References:}

1. Ferrie C. Seizures, epilepsy and other paroxysmal disorders. In: McIntonsh N, Helms PJ, Smyth RL, eds. Forfar\&Arneil's Textbook of Pediatrics, $6^{\text {th }}$ ed. Churchill Livingstone 2003.

2. Tsuboi T. Prevalence and incidence of epilepsy in Tokyo. Epilepsia 1988; 29:103-10.

3. Osuntokun BO, Adeuja AOG, Nottidge VA. Prevalence of the epilepsies in Nigerian Africans: a community-based study. Epilepsia1987;28:272-9.

4. Nicoletti A, Reggio A, Bartoloni A. Prevalence of epilepsy in rural Bolivia: a door-todoor survey. Neurology 1999;53:2064-9.

5. Chowdhury AKMN, Alam MN, Au SMK. Dasher kandi Project Studies. Bangladesh Med Res Council Bull 1981; 7: 22-39.

6. Adams RD, Victor M. Principles of 'Neurology. $6^{\text {th }}$ ed. MC Graw Hill Book Co. NY 1997.

7. Charles B. Clayman E. American Medical Association. The American Medical Association's Encyclopedia of Medicine. New York:Random; 1989.

8. Donaldson J. Seizures in rats associated with divalent cation inhibition of Na+-K+ATPase. Can J Biochem. 1971; 49:1217- 1224.

9. Wallwork JC. Zinc and the central nervous system. Prog Food Nutr Sci. 1987;11:203247.

10. Itoh M, Ebadi M. The selective inhibition of hippocampal glutamic acid decarboxylase in zinc-induced epileptic seizures. Neurochem Res. 1982;7:1287-1288.

11. Smith WG, Bone I. Copper, zinc and magnesium plasma levels in epilepsy. J NeurolNeurosurg Psychiatry. 1982;45:1072.

12. Westbrook GL, Mayer ML. Micromolar concentrations of $\mathrm{Zn}$ antagonize NMDA and GABA response of hippocampal neurons. Nature. 1987;328:640-643.

13. Frederickson CJ, Moncrieff DW. Zinc-containing neurons. Biol Signals. 1994;3:127-139.

14. Manuel CG, Laura PG, Carmen GL, Daisy E. The Influence of Valproic Acid and Carbamazepine :Treatment on Serum Biotin, Zinc and Copper Levels and on Biotinidase Activity. J Child Neurol. 2011; 26 (12): 1522-1524. 
15. Frederickson CJ. Neurobiology of zinc-containing neurons. Int Rev Neurobiol. 1989;31:145-238.

16. Seymour CA, Weatheral DJ, Ledingham JGG, Warrel DA. Trace metal disorders. Oxford Textbook of Medicine. $3^{\text {rd }}$ ed. Oxford University Press, UK 1996.

17. Manuel CG, Laura PG, Carmen GL, Daisy E. The Influence of Valproic Acid and Carbamazepine :Treatment on Serum Biotin, Zinc and Copper Levels and on Biotinidase Activity. J Child Neurol. 2011; 26 (12): 1522-1524

18. Maret W, Sandstead HH. Zinc requirements and the risks and benefits of zinc supplementation. J Trace Elem Med Biol 2006;20:3-18.

19. Ploysangam A, Falciglia GA, Brehm BJ. Effect of marginal zinc deficiency on human growth and development. J Trop Pediatr 1997;43:192-8

20. Sözüer DT, Barutçu UB, Karakoç Y, Yalçin E, Onen S. The effects of antiepileptic drugs on serum zinc and copper levels in children. J Basic ClinPhysiolPharmacol. 1995;6(34):265-9

21. Tekin D, Taşdemir HA, Saraymen R. The Effects of Antiepileptic Drugs on Serum and Hair Trace Element Levels.Antiepileptikİlaçların Serum VeSaçtaEser Element DüzeylerineEtkileri.Ankara Üniversitesi Tıp FakültesiMecmuası 2008; 61(2):73-76.

22. Verotti A., Basciani F., Trotta D., Pomilio MP., Morgese G.,ChiarelliF.Serum copper, zinc, selenium, glutathione peroxidase and superoxide dismutase levels in epileptic children before and after 1 year of sodium valproate and carbamazepine therapy. Epilepsy Res. 2002 Jan;48(1-2):71-5.

23. Barbeaus A, Donaldson J. Zinc, taurine, and epilepsy. Arch Neurol 1974; 30(1):52-8.

24. Saboktakin L, Barzegar M, Hagh Jo AG, Emamalizadeh M. Study on serum Copper and Zinc level of children with epilepsy during long term therapy with anticonvulsants. Life Sci J 2012;9(4):1250-54.

25. Diop AG, Agbohoui OL, Ndiaye M, Sene F, Ndiaye JP. Prévalence de l'épilepsie en milieu scolairesénégalais. Congrès de la P.A.A.N.S.1996: 19-23.

26. Nouri, S, Devinsky O. Sudden Unexpected Death in Epilepsy. J Neurol 2004;238:262264

27. Ogunlesi T, Ogundeyi M, OlowuA . Pattern of childhood Epilepsies in Sagumu, Nigeria; Indian J Pediatr2009; 76:385-89.

28. Osuntokun BO, Rose FC. Neuroepidemiology in Africa.J ClinNeuroepide.London, UK: Pittman Medical; 1980;3: 57-86.

29. Annegers $J F$, Rocca WA, Hauser WA. Causes of epilepsy: contributions of the Rochester Epidemiology Project. Mayo ClinProc1996;71:570-75.

30. Meinardi H, Scott RA, Reis R, Sander JW, EEG in diagnosis, classification \& management of patient with Epilepsy. Epilepsia2001;42:136-49.

31. Benbadis SR, Tatum WO. Overinterpretation of EEGs and misdiagnosis of epilepsy. J ClinNeurophysiol. 2003;20:42-4.

32. Flink R, Pedersen B, Guekht AB. Guidelines for the use of EEG methodology in the diagnosis of epilepsy.ActaNeurolScand 2002;106:1-7

33. SherifaA,MoustafaM,NaglaE.Blood Levelsof Trace Elements,Electrolytes,andOxidative Stress/Antioxidant Systems in Epileptic Patients with antiepileptic therapy J PharmacolSci 2004;96:465-74.

34. Yanagisawa, H. Clinical aspects of zinc deficiency. J of the Japan Med Asso 2002; 127 (2): 261-268. 
35. Yanagisawa H, Kurihara N, Wada O. Zinc - Extensive blood and urine biochemistry and immunological tests(2). Japan J of Clin Med 1999; 57 (extra issue):282-286. 